\title{
DEVELOPMENT OF THE STEREOMETRIC METHOD TO THE ANALYSIS OF ECONOMIC CATEGORIES AND PROCESSES AND ITS APPLICATION IN SECURITY AND TAXATION
}

\author{
Vladimir Nusinov ${ }^{1}$, levgeniia Mishchuk ${ }^{2}$, Yaroslav Izmaylov ${ }^{3}$
}

\begin{abstract}
The article is aimed at the enhancement of the stereometric approach to analysing economic categories and processes and investigating directions of its application in the science of security and taxation. Methodology. The methodological basis of the study consists of general scientific methods of analysis and synthesis, a comparative study of existing models of economic categories, which are based on the stereometric approach. The empirical method is used to describe the problem of using a stereometric approach to determining the economic security of an enterprise. The results of the study. The article demonstrates that modern realities increasingly require spatial thinking from economists, thus conditioning the appearance of 3D models of some economic categories in economic research papers. A number of stereometric elements have been applied by both foreign and Ukrainian scholars in the economic sphere for several decades. The article points out that no current model could claim the complete realization of the stereometric approach as an independent unidirectional array of the content of principles and methods of analysing economic categories and processes. There are also determined regularities not considered by other scientists, as well as current problems and omissions. Practical implications. There are substantiated differences between the stereometric and graphical methods of economic analysis. The stereometric approach is suggested to be meant as one of the economic analysis approaches based on visualization of economic categories and processes on the basis of geometric solids allowing qualitative and quantitative assessment of the level and dynamics of the selected array of indicators put into a single graphical model. There is revealed essence and principles of the stereometric approach use in the economy and in the science of security in particular. Economic security is treated as one of the ternary nature being resources, processes and a condition simultaneously. The article suggests a pyramid to determine economic security and proves that changes of quality, speed, and quantity of business processes expressed by changes of corresponding angles of the pyramid impact both the condition and the general level of economic security. Relevance/originality. The presented proposals on enhancing the stereometric approach create a theoretical foundation for applied research in various industries. The enhanced stereometric approach enables building a general-theoretical concept of economic security considering its connections with such notions as competitiveness and development.
\end{abstract}

Key words: analysis, economic security, taxation, process, stereometric approach.

JEL Classification: B49, C13, C38, C81, H32, Y10

\section{Introduction}

The economic science is now experiencing the transition from 2-dimensional to "stereometric" semantics that assigns at least three projections, each of them determining a certain kind of relationship (assessment) (Tulchinskiy, 2017). At the same time, the approach to formation and assessment of economic categories through their type and kind remains dominant claiming to offer completeness of analysis and induction. However, modern realities are increasingly requiring spatial thinking of economists. Apparently, space and time together create a structure containing

\footnotetext{
Corresponding author:

${ }^{1}$ Kryvyi Rih National University, Ukraine.

E-mail: tdutybz.077@gmail.com

ORCID: https://orcid.org/0000-0002-9293-2969

${ }^{2}$ Kryvyi Rih National University, Ukraine.

E-mail: mishchuk.ievgeniia@gmail.com

ORCID: https://orcid.org/0000-0003-4145-3711

${ }^{3}$ Kryvyi Rih Economic Institute of Kyiv National Economic University named after Vadym Hetman, Ukraine.

E-mail: izmaylov_yo@kneu.dp.ua

ORCID: https://orcid.org/0000-0003-4853-205X
} 
the whole reality, beyond which economic categories cannot be understood to the full extent. So, threedimensional research models in economic works for studying individual economic categories and processes are quite objective. Nevertheless, their disclosure is limited by specific, in some cases highly specialized aims and tasks of a particular investigation. At that, the methodological approach underlying these models remains understudied.

In the scientific economic literature, the most popular models applying stereometric semantics are the following: Maslow's pyramid of needs, (Maslow, 1943), D. Scott Sink's performance management cube (Sink, 1985), C. J. McNair, Richard L. Lynch and Kelvin F. Cross's performance pyramid (McNair, Lynch, Cross, 1990), A. Moceng and P. Bredup's threedimensional model of economic processes efficiency (Moceng, Bredup, 1993), A. Neely, C. Adams, M. Kennerly's performance prism (Neely, Adams, Kennerly, 2003). The main difference we pay attention to consists in the fact that the first three of the above models are just visual reflections of their authors' scientific views but the other two are used not only as a visual graphical interpretation but also for assessing indicators determined in their basis. Western researchers' models have made the basis for Ukrainian developments. Numerous new models have been developed on the basis of the last two of the abovementioned models, which were updated considering the specific character of companies of various industries, transformed or used for another research direction (the science of security in particular). O. M. Liashenko's pyramid of efficiency of company economic interests harmonization (Liashenko, 2008); O. I. Oleksiuk's ternary informationcentred model (the pyramid) of economic performance measurement (Oleksyuk, 2009; Oleksyuk, 2008); A. Yu. Kretova's three-dimensional model of industrial company performance measurement (Kretova, 2011); O. A. Kirichenko's (Kirichenko, 2011) and L. O. Korchevska's (Korchevska, 2016) model (the cube) of economic security assessment; O. I. Belei's trade company performance measurement prism (Beley, 2012); N. V. Biloshkurivska's three-dimensional model of strategic provision of the economic and organizational mechanism of company economic security (Biloshkurska, 2012); H. A. Zhuchkova's three-dimensional model of determining company performance efficiency (Zhuchkova, 2013); M. I. Ishchenko's pyramid of measuring resource provision of company financial and economic performance (Ishchenko, 2013); M. P. Sahaidak's graphical interpretation (the rectangular prism) of assessment of service company internal marketing potential (Sahaidak, 2015); T. Ye. Chebanova and O. V. Koretska's three-dimensional model of resource intensity of providing port company economic security (Chebanova, Koretska, 2015) are some of them.
Despite the fact that a number of stereometric elements have been used by both foreign and national scholars for already several decades, it should be noted that current scientific theories lack systematicity. Undoubtedly, the mentioned models solve certain applied tasks but none of them considers properties of geometric figures and rules of their construction. Besides, there are currently no models that could claim complete elucidation of the stereometric approach as an independent unidirectional array of the content of principles and methods of analysing economic categories and processes.

The article is aimed at the enhancement of the stereometric approach to analysing economic categories and processes and investigating directions of its application in the science of security and taxation.

\section{Existing trends in stereometric semantics application in economic research}

In thiswork, we donotconsidereconomic developments that use stereometric semantics but the models based on which do not relate to stereometry and for this reason are not based on the stereometric approach. For instance, in (Holden, 2014) the stereometric terminology is not applied in its proper sense, the authors study the liquidity cross section structures; (Gerasymenko 2017) deals with three planes of competitiveness studies (horizontal, vertical, potential).

The research of existing approaches to the analysis of economic categories and processes where particular elements of stereometry are used reveals the researchers' various views that can be grouped into three directions.

In the first group, the researchers apply threedimensional models but do not use geometric solids or call the approach like that a stereometric one. This direction is the widest and comprises a great number of scientific developments.

Investigations of the second directions focus on the approach the researchers call stereometric. This is clearly illustrated in works by P. I. Zavorotnii who substantiates reasonability of applying the stereometric approach to assessing dynamics of determinants of economic development and its possibilities in this (Zavorotnii, 2015). We agree with the researcher that assessment of indicators not associated in the discriminant model results in impossible application of classical factor analysis methods but the stereometric method allows obtaining the general idea of the dynamics of the selected array of indicators, putting the dynamics in a single graphical model and calculating the degree of the total change of the indicators in the accounting period (Zavorotnii, 2015). Here, the researcher delineates a triangle with the vertexes in different planes. The principal difference of this direction from the previous one is the explicit reference to the stereometric approach. However, P. I. Zavorotnii does not specify features of the approach or elaborate the idea of its specific application. 
The third direction is characterized by the use of geometric solids (cubes, pyramids prisms). But the researchers call this a graphical or mathematical method that does not exclude its stereometric essence. In particular, the author of the company resource provision pyramid states that it is underlain by the graphical analysis method (Ishchenko, 2014).

Nevertheless, we are convinced that the stereometric approach to the analysis of economic categories and processes should not be identified with the graphical method of economic analysis providing for geometrical representation of functional dependencies by one plane lines and used mainly for fast determination of function values by the corresponding argument value, as well as for simple visual demonstration of obtained data. In our opinion, the stereometric approach provides for investigation using geometrical figures, points of which lie in different planes, whereas economic analysis applies the following kinds of graphs: comparison diagrams, time diagrams, distribution curves, correlation diagrams, statistical cartograms. Besides, the stereometric approach should be suitable for integrating the massif of economic knowledge in order to substantiate properties and regularities of formation and development of relatively new economic categories and processes. Its application should also facilitate the enhancement and harmonization of the existing concepts. The mentioned is especially topical for the current state of one of relatively new and actual directions in economics - the science of security when requirements of explaining and assessing its basic notions (economic security, threats, guarantees, etc.) have conditioned the appearance of a number of conceptual approaches. These approaches, on the one hand, have integrated knowledge from various areas but, on the other hand, have not completely considered actual relations between separate notions (competitiveness, development, etc.) and, consequently, produced insufficiently correct explanations. This results in complication caused by the necessity of defining and measuring related and derivative notions.

Multidimensional matrixes are widely used to determine the level of efficiency of the implementation of certain security measures or the impact of various factors on the state of economic security. One of the most widely used is a three-dimensional matrix, this fact being explained by the clearness of data presentation in the form of "a kind of a cube" oriented by certain axes reflecting values of a particular group of parameters (Kirichenko, Shykova, 2011). This model is supplemented in (Korchevska, 2016) where the cube is called a form of visualization of the company economic security assessment model. Here, a company's economic security is suggested to be assessed on the basis of convolving assessments of quantitative and qualitative parameters of providing resources and business-processes and parameters of harmonization of stakeholders' interests. From the mathematical point of view, a company's economic security assessment can be presented by a point in a cube (a vector form) or a parallelepiped volume in the unit cube volume (a scalar form) as the maximum value of each axis of the cube is equal to one (Korchevska, 2016).

To assess other economic security based notions, the following three-dimensional models are used:

- the three-dimensional model of strategic provision of economic security, to form which N. V. Biloshkurska suggests application of the current assets to equity ratio (the values to be plotted on the X-axis), the indicator of the economic and organizational mechanism of a company's economic security (the values to be plotted on the X-axis) and the indicator of company market (the values to be plotted on the $\mathrm{Z}$-axis) (Biloshkurska, 2012); - the three-dimensional model of resource intensity of port company economic security (Chebanova, Koretska, 2015). Unlike in the previous work (Biloshkurska, 2012), here are no empirical data or quantitative methods of assessment. Besides, the name of the model contains the stereometric terminology, which does not basically relate to the stereometric approach.

It should be noted that economic security is not separated from other notions. On the one hand, it is ternary by nature being resources, processes and a state simultaneously, as well as a specific structure i.e. integration with defined economic notions. Thus, A. Yu. Kretova has developed proposals concerning the complex measurement of company performance considering both time and type aspects and suggests measuring the performance using the three-dimensional synthetic-prospecting model based on measurement of three components - company performance, potential and economic security, as well as considering the three-time states - retrospective, current, and future. Here, economic security is called an indicator of the current performance of a company determined by the delta between desired and actual levels of harmonization of internal and external entities' interests (Kretova, 2011). So, the formation of the company's economic security and its measurement should be accompanied by consideration of conditions of the company's functioning in the external (in most cases - competitive) environment. Apparently, during the process of development, the company economic security also undergoes changing and this fact should be considered in corresponding models as well. Along with that, one of the key standards of substantiation assessment of the model is how well its application enables forecasting the future state.

\section{Company tax security through the application of a stereometric method}

Efficient tax security of the company creates conditions for the stability of its economic situation and provides the basis for development, income growth, solvency, liquidity, creditworthiness, and profitability 
with a minimal risk level affecting directly the financial position and business cooperation potential.

Modern conditions of application of the investment and innovation development of the world economy model require the use of an integrated approach to the formation of theoretical, methodological, and organizational principles for the application of a stereometric method in tax security, which takes a key place in the structure of company economic security.

The target of tax security is to determine the optimal measures, forms, and methods of the tax burden, minimize economic entities tax risks depending on the specifics of the industry, ensure the possibility of maintaining and increasing the results of its financial and economic activity.

In order to apply a stereometric method to company tax security, it is necessary to determine the factors of influence estimating the level and dynamics of the selected aggregate of indicators both quantitatively and qualitatively.

The main factors influencing company tax security are as follows: the continuous development of information systems and technologies; scientific and technical potential of the staff; modernization of the internal accounting and tax payment model; company depreciation policy; development of accounting payment system; failure to comply with tax legislation requirements; arithmetical and methodological mistakes in determining the tax base of gross income and gross expenditures; understatement of tax payments by illegal methods; limited liquidity and solvency; low payment discipline of suppliers and contractors.

A senior manager can take his own decision upon the factors having the greatest impact on tax security, depending on the company type and sphere of financial and economic activity. Besides, using a stereometric method, it is easy to assess both quantitatively and qualitatively the level and dynamics of the selected indicators aggregate built up in a single graphical model for providing tax security as a component of company economic security.

\section{Critical analysis of the basic models founded upon the stereometric method}

Application of the stereometric approach to the formation and assessment of economic security can provide adequate tracing of cause-and-effect relations between both its structural elements and between itself and other economic notions. Let us see it analysing the models based on the stereometric approach that are dealt with in (Neely, Adams, Kennerley, 2003), (Oleksyuk, 2009; Oleksyuk, 2008), (Liashenko, 2008), (Ishchenko, 2013), (Sahaidak, 2015) (Table 1).

Despite different purposes of the models under consideration, they are built on the basis of two solids - a prism and a pyramid. A. Neely, C. Adams, and M. Kennerley's performance prism appeared first and is based on interconnected elements of performance management. The following statements underlie the model:

- organizations achieve their objectives (i.e. fulfil their tasks) satisfying both the stakeholders' and their own desires and needs at the expense of a higher degree of return and efficiency as compared with their competitors. Not arguing with the point, we note the absence of coordination with the external competitive environment;

- return means the degree of stakeholders' requirements satisfaction: performance is a criterion of how a company's resources are used to provide the defined level of harmonization in economic terms. Apparently, the model provides for studying available resources but the process of their formation is not investigated;

- the level of business efficiency is the function of performance and return of actions undertaken (A. Neely, C. Adams, and M. Kennerley, 2003). Consideration of the continuous series of interrelated actions is a manifestation of the process approach but the authors do not show how qualitative, quantitative, and/or temporal change of actions will impact the indicators under study.

Table 1

Basic models of economic categories based on the stereometric approach

\begin{tabular}{|c|c|c|c|c|c|}
\hline & \multicolumn{5}{|c|}{ Models } \\
\hline & A. Neely's prism & $\begin{array}{l}\text { O. I. Oleksiuk's } \\
\text { pyramid }\end{array}$ & O. M. Liashenko's pyramid & $\begin{array}{l}\text { M. I. Ishchenko's } \\
\text { pyramid }\end{array}$ & M. P. Sahaidak's prism \\
\hline 1 & 2 & 3 & 4 & 5 & 6 \\
\hline 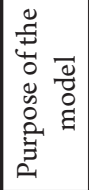 & $\begin{array}{l}\text { Company } \\
\text { performance } \\
\text { measurement }\end{array}$ & $\begin{array}{l}\text { Information- } \\
\text { centred assessment } \\
\text { of economic } \\
\text { performance } \\
\text { measurement }\end{array}$ & $\begin{array}{l}\text { Determination of efficiency } \\
\text { of company economic } \\
\text { interests harmonization as } \\
\text { the instrument of measuring } \\
\text { its economic security }\end{array}$ & $\begin{array}{l}\text { Assessment of } \\
\text { resource provision } \\
\text { of company financial } \\
\text { and economic } \\
\text { performance }\end{array}$ & $\begin{array}{l}\text { Assessment of the level of } \\
\text { resource, process and strategic } \\
\text { prerequisites for achieving } \\
\text { designed indicators of a } \\
\text { company's internal marketing }\end{array}$ \\
\hline 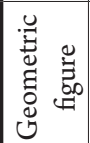 & Triangular prism & $\begin{array}{l}\text { Pyramid with the } \\
\text { triangular base }\end{array}$ & $\begin{array}{l}\text { Pyramid with the } \\
\text { quadrilateral base }\end{array}$ & $\begin{array}{l}\text { Right prism with the } \\
\text { regular pentagonal } \\
\text { base }\end{array}$ & \\
\hline
\end{tabular}

Source: developed by the author on the basis of the systematized works (Neely, Adams, Kennerley, 2003; Oleksyuk, 2009; Oleksyuk, 2008; Liashenko, 2008; Ishchenko, 2013; Sahaidak, 2015) 
In 2008 in Ukrainian scientific literature, there appeared two pyramids - by O. I. Oleksiuk and by O. M. Liashenko. O. I. Oleksiuk's main idea consists in the fact that basic factors such as information, time, and traditional resources taken together impact company performance and their optimum balance allows reaching the highest level of performance and management efficiency (Oleksyuk, 2009; Oleksyuk, 2008). In our opinion, the principal omission of the model is, first, that information and time are kinds of traditional resources. Besides, in real business conditions, there are parameter gaps in time, such as, for instance, production gaps. In our opinion, in this case, time is of ternary nature, being a production resource, a process practicability factor and a property of contradiction (threat) expression. Second, it is not reasonable to neglect the non-traditional resources of a company (reputational, organizational, innovative, intellectual, and administrative ones. The first four kinds are rather well covered in the scientific literature. We suggest treating the remaining ones as additional advantages resulting from relations (family, friendly, political, business, etc.) of owners or top management of a company with officials at government and other bodies (organizations) connected with the company's activities in order to achieve the company's objectives. Third, the model does not consider processes, due to which the mentioned resources facilitate achievement of economic results.

In substantiating the second model-pyramid, the last of the discovered omissions are eliminated. The attempt is undertaken to take into account the process of company economic interests' harmonization, which is, according to O. M. Liashenko, in constant motion and, therefore, does not allow choosing and fixing criteria of this process. Another important idea suggested by the author is the impossibility of assessing company economic interests' harmonization on a plane and the necessity of applying three-dimensional images (Liashenko, 2008). Agreeing completely with the author, we note the omission of the model, which, despite the fact that O. M. Liashenko considers the process-oriented criterion of the company economic interests' harmonization efficiency, and which in our opinion consists in stationarity of the model. This can be explained by the use of not a dynamic but a static value the degree of stakeholders' requirements satisfaction in terms of their economic interests' harmonization as the mentioned criterion.

In 2013, M. I. Ishchenko's pyramid of resource provision of a company's financial and economic performance appeared in the scientific literature. The pyramid considers a number of requirements, unified directivity of group indicators of the whole system and possibility of forecasting indicator dynamics directivity being among them. M. I. Ishchenko states the necessity of using the dynamic approach as the failure of absolute values of the resource components as of a certain date to form the database for analytical assessment of the company's development prospects (Ishchenko, 2013). However, in our opinion, the process approach should be applied in addition to dealing with the categories under study in their dialectic development, considering cause-and-effect relations and hierarchy based on the retrospective analysis of the company's behaviour within a certain time period. To a certain extent, this omission is considered in the next model - M. P. Sahaidak's prism.

In 2015, M. P. Sahaidak identified the dependency of a service company's performance on the efficiency of forming and using resources and elements of the internal marketing system and suggested the right prism of measuring the company's internal marketing system potential. One of the principal ideas of the model is the statement that companies considering their personnel to be their core asset will finally win the competition and be able to reach the designed level of performance with fewer resources spent. Resource provision of the service company performance is presented as a regular pentagonal prism illustrating the level of the internal marketing potential, enables forecasting the company's possibilities on the relevant market in the short-term and long-term run and determining problems with the internal marketing system, resource provision, and the front line personnel (Sahaidak, 2015). However, in spite of the mentioned advantages, the suggested approach contains omissions. Thus, the author does not consider a higher correlation between similar brands in a better space than between different brands that results in a faster pace of displacement. Here, the similarity based on total utility rather than on attributes only determines products similar in higher paces of displacement (Dotson, 2018). Besides, the model does not consider how the internal environment impacts on service companies' incomes influence those of their personnel (Juhn, 2018).

In our opinion, if graphical interpretation aided by the stereometric approach is used to visualize scientific ideas, it is sufficient to explain the choice of the geometric solid in general. However, this condition is not sufficient if economic categories and processes are to be explained. The choice of this or that shape requires additional substantiation from the economic point of view. Particularly, the type of polyhedron chosen should be explained economically. If the base is a triangle, its types (scalene, equilateral, acute, obtuse) should be substantiated in economic terms. In case of a quadrilateral (reflex, convex, nonconvex, arbitrary; elliptical, parabolic, hyperbolic; a parallelogram, a rhombus, a square, a rectangle, a trapezoid, an isosceles trapezoid, a kite), as well as a pyramid and a prism, the choice should also be provided with reasonable economic substantiation. If it is not done, scientists focus on the figure shapes and sizes of its elements but not on its other properties. Let us exemplify this by geometric figures of the models under study. Elements of the solid bases are given in Table 2. Note that dash means that the element is not available in the solid. 
Vol. 5, No. 4, 2019

Table 2

Interpretation of bottom base elements of figures in models under study

\begin{tabular}{|c|c|c|c|c|c|}
\hline \multirow[b]{2}{*}{ Elements } & \multicolumn{5}{|c|}{ Model and characteristics of corresponding elements of solids } \\
\hline & $\begin{array}{l}\text { A. Neely } \\
\text { at al. prism }\end{array}$ & $\begin{array}{c}\text { O. I. Oleksiuk's } \\
\text { pyramid }\end{array}$ & $\begin{array}{l}\text { O. M. Liashenko's } \\
\text { pyramid }\end{array}$ & M. I. Ishchenko's pyramid & M. P. Sahaidak’s prism \\
\hline 1 & 2 & 3 & 4 & 5 & 6 \\
\hline Figure vertexes & - & Result & Not specified & Strategic resources & - \\
\hline Base & Not specified & Not specified & Not specified & $\begin{array}{l}\text { Constructed of vectors- } \\
\text { axes }\end{array}$ & Constructed of vectors-axes \\
\hline $\begin{array}{l}\text { Bottom base } \\
\text { vertexes }\end{array}$ & Not specified & $\begin{array}{l}\text { Information; } \\
\text { resources, time }\end{array}$ & Not specified & $\begin{array}{l}\text { Material resources: } \\
\text { financial, labour, material } \\
\text { and technical resources } \\
\end{array}$ & $\begin{array}{l}\text { Five factors impacting the } \\
\text { internal marketing system }\end{array}$ \\
\hline Bottom base & $\begin{array}{l}\text { Stakeholder's } \\
\text { contribution }\end{array}$ & Not specified & $\begin{array}{l}\text { Polygon of economic } \\
\text { interests of the external } \\
\text { environment of a } \\
\text { company }\end{array}$ & $\begin{array}{l}\text { Resource provision } \\
\text { polygon }\end{array}$ & $\begin{array}{l}\text { Resources, the use of which } \\
\text { enables the formation of the } \\
\text { viable internal marketing system }\end{array}$ \\
\hline $\begin{array}{l}\text { Vectors-axes in } \\
\text { bottom base }\end{array}$ & Not specified & Not specified & Not specified & $\begin{array}{l}\text { Radiuses of the circle } \\
\text { representing the } \\
\text { maximum potential of } \\
\text { company traditional } \\
\text { resources }\end{array}$ & Resource use level \\
\hline $\begin{array}{c}\text { Bottom base } \\
\text { area }\end{array}$ & Not specified & Not specified & $\begin{array}{l}\text { Area of the polygon of } \\
\text { external stakeholders' } \\
\text { interests harmonization }\end{array}$ & $\begin{array}{l}\text { Area of the pyramid base } \\
\text { - an area of the resource } \\
\text { provision polygon }\end{array}$ & $\begin{array}{l}\text { The area of the pentagon reflects } \\
\text { the efficiency of the use of the } \\
\text { resource base in provision of the } \\
\text { total performance of the internal } \\
\text { marketing system }\end{array}$ \\
\hline
\end{tabular}

Source: developed by the author on the basis of the systematized works (Neely, Adams, Kennerley, 2003; Oleksyuk, 2009; Oleksyuk, 2008; Liashenko, 2008; Ishchenko, 2013; Sahaidak, 2015)

So, a number of elements in all the models except for M. P. Sahaidak's prism are not treated ("Not specified" in Table 2).

The bottom base of practically all the models characterizes resource provision amounting to stakeholders' contribution. Comparison of interpretations of the bottom bases of A. Neely, C. Adams, and M. Kennerley's (Neely et al., 2003) and M. P. Sahaidak's prisms show that both models specify main stakeholders: the business owner and the personnel. But in M.P Sahaidak's prism, top management is additionally specified that is not considered in the performance prism where investors, customers, suppliers, state institutions, etc. are mentioned instead (Neely et al., 2003). When determining factors impacting the internal marketing system, M. P. Sahaidak mentions, among others, building partnering relationships between top management, personnel, and other stakeholders of a company but the group of other stakeholders is not clarified. When characterizing company business processes, its personnel, customers, suppliers, state institutions, etc. are mentioned among key stakeholders (Sahaidak, 2015).

Analysis of contributions (resources) required by the company from certain stakeholder groups shows common aspects in the models (Table 3).

\section{Table 3}

Types of resources (bottom base) in models under study

\begin{tabular}{|l|l|l|}
\hline \multicolumn{1}{|c|}{ Stakeholders } & \multicolumn{1}{|c|}{ Types of resources in A. Neely at al. prism } & \multicolumn{1}{|c|}{ Types of resources in M. P. Sahaidak's prism } \\
\hline Business owner & \multicolumn{1}{|c|}{2} & \multicolumn{1}{c|}{3} \\
\hline Personnel & $\begin{array}{l}\text { Intellectual capital, professionalism, client- } \\
\text { centeredness }\end{array}$ & $\begin{array}{l}\text { Financial, material, technical resources; information- } \\
\text { communication and intellectual resources; innovative resources }\end{array}$ \\
\hline Top management & - & $\begin{array}{l}\text { Labour, social, organizational; intellectual, innovative, and } \\
\text { information-communication }\end{array}$ \\
\hline Customers & Loyalty and profitability; & $\begin{array}{l}\text { Organizational and administrative; information- } \\
\text { communication, and intellectual }\end{array}$ \\
\hline Suppliers & Equipment, materials and additional service & Labour, social, organizational \\
\hline State institutions & $\begin{array}{l}\text { Regulatory support of business activities and } \\
\text { facilitation of authorization procedures }\end{array}$ & - \\
\hline
\end{tabular}

Source: developed by the author on the basis of the systematized works (Neely et al., 2003; Sahaidak, 2015) 
In O. I. Oleksiuk's and M. P. Ishchenko's models, resources are not divided among stakeholders (Oleksyuk, 2009; Oleksyuk, 2008; Ishchenko, 2013).

Three of the five models suggest defining the area of the bottom base. O. M. Liashenko marks the base area as a key factor influencing the result - the economic security level - and depicts its value dynamics: "the smaller the area of the polygon of the company external economic interests harmonization is and the lower the level of interests harmonization of its internal environment that limits the volume of the pyramid under study and, in many cases, slows down the process of external economic interests harmonization is, the smaller the pyramid volume and the lower the efficiency of the company economic interest harmonization and, consequently, the company's economic security level and capability of increasing this level are (Liashenko, 2008).

In M. I. Ishchenko's model, the base is constructed of vectors-axes and defines the level of formation and efficiency of use of traditional resources. Each vector in its limit value is the radius of the circle depicting the maximum potential of the company's traditional resources (the ideal option) (Ishchenko, 2013). M. P. Sahaidak treats the segments constructed on the base from its centre to the polygon vertexes as sides of equilateral triangles forming the prism base (a regular pentagon). According to the author, the segments enable reflecting the level of formation and efficiency of application of the resource base of the company internal marketing system performance (Sahaidak, 2015).

In M. I. Ishchenko's model, limit values of the pyramid base area $(S)$ are determined: the maximum pyramid base area that corresponds to the maximum value of the state and efficiency of traditional resources use: $S$ $=1.732$; the high level: $S \geq 1.109$; the medium level: $1.108 \leq S \leq 0.622$; the low level: $S<0.622$ (Ishchenko, 2013). In the other models under study, base areas do not have economic characteristics of this kind.

Let us consider the interpretation of the main elements of the upper base of the prisms. As the upper base is not provided in pyramids, the models of O. I. Oleksiuk, O. M. Liashenko, and M. I. Ishchenko are not tabulated (Table 4).

M. P. Shaidak's prism is called idealistic, which is evidence that with real data areas of the upper and bottom bases may not conform to each other. At the same time, the author does not consider economic substantiation of the situation if the number of factors of stakeholders' interests and needs (the upper base vertexes) change, e.g. if it grows due to challenges of a new market environment, how will the geometric figure change? The situation changes may result in an increasing number of not only the upper base vertexes but also edges, diagonal planes, etc.

Thus, in their performance prism, A. Neely at al. provides a more general interpretation of the upper base as compared to that of M. P. Sahaidak.

In M. P. Sahaidak's prism, creation of a positive image of a company as an employer and a service provider in order to keep its skilled personnel and attract the new one refers to the indicator impacting the level of stakeholders' interests satisfaction that, consequently, facilitates the company competitiveness and value increase (Sahaidak, 2015).

Let us consider the interpretation of other elements of the solids (Table 5).

So, all the geometric solids under study altitudes end at the bottom base. No scientist substantiates why exactly this is in this way. In regular prisms, altitudes coincide with a lateral edge. However, with actual data the prism is no longer "idealistic"; it turns into, for instance, an oblique one. According to the stereometry rules, its altitude is a perpendicular segment that starts from a base (often from an upper vertex) and ends in the second base of the prism. But what point the altitude of the oblique prism is projected into cannot be determined without specifying additional conditions.

Of all the pyramids under study, the lateral faces of O. M. Liashenko's model are only interpreted. The lateral faces of the prisms under study are interpreted similarly: strategies and possibilities. At that, in the prism of A. Neely, C. Adams, and M. Kennerley strategies are divided into corporate, subdivision, brand, service, operational, etc. (Neely, Adams, Kennerley, 2003), in M. P. Sahaidak's prism they are not characterized. This is correct for possibilities, too. In the first prism, they are characterized as a combination of a company's personnel, work practices, technology and infrastructure, which together enable creating consumer and added values through business processes.

Table 4

Interpretation of upper base elements of solids in models under study

\begin{tabular}{|l|l|l|}
\hline \multirow{2}{*}{\multicolumn{1}{c|}{ Elements }} & \multicolumn{1}{c|}{ A. Neely at al. prism } & \multicolumn{1}{c|}{ M. P. Sahaidak's prism } \\
\cline { 2 - 3 } \multicolumn{1}{c|}{1} & \multicolumn{1}{|c|}{2} & \multicolumn{1}{c|}{3} \\
\hline Upper base & Stakeholders satisfaction & The satisfaction of stakeholders' needs and interests \\
\hline Upper base vertexes & Not specified & Factors of satisfaction of stakeholders' needs and interests \\
\hline Upper base vectors-axes & Not specified & Interests satisfaction levels \\
\hline Upper base area & Not specified & $\begin{array}{l}\text { The efficiency of use of the resource base in provision of the total } \\
\text { performance of the internal marketing system }\end{array}$ \\
\hline
\end{tabular}

Source: developed by the author on the basis of the systematized works (Neely et al., 2003; Sahaidak, 2015) 
Table 5

Interpretation of other elements of solids under study

\begin{tabular}{|c|c|c|c|c|c|}
\hline \multirow[b]{2}{*}{ Elements } & \multicolumn{5}{|c|}{ Model and characteristics of corresponding elements of solids } \\
\hline & $\begin{array}{l}\text { A. Neely } \\
\text { et al. prism }\end{array}$ & $\begin{array}{c}\text { O. I. Oleksiuk's } \\
\text { prism }\end{array}$ & O. M. Liashenko’s pyramid & $\begin{array}{l}\text { M. I. Ishchenko's } \\
\text { pyramid }\end{array}$ & M. P. Sahaidak's prism \\
\hline 1 & 2 & 3 & 4 & 5 & 6 \\
\hline Lateral faces & $\begin{array}{l}\text { Strategies; } \\
\text { possibilities; } \\
\text { processes }\end{array}$ & Not specified & $\begin{array}{l}\text { External stakeholders' economic } \\
\text { interests }\end{array}$ & Not specified & $\begin{array}{l}\text { Strategy and level of } \\
\text { company possibility use }\end{array}$ \\
\hline Lateral edges & Not specified & Not specified & Not specified & Not specified & Not specified \\
\hline Diagonal planes & Not specified & Not specified & Not specified & Not specified & $\begin{array}{l}\text { Efficiency of basic business } \\
\text { processes }\end{array}$ \\
\hline Solid altitude & Not specified & Not specified & $\begin{array}{l}\text { Level of internal economic } \\
\text { interests' harmonization }\end{array}$ & $\begin{array}{l}\text { Strategic resources } \\
\text { amount }\end{array}$ & $\begin{array}{l}\text { Not specified but noted that } \\
\text { the prism altitude equals the } \\
\text { lateral edge length }\end{array}$ \\
\hline Solid volume & Not specified & Not specified & $\begin{array}{l}\text { Company stakeholders' interests } \\
\text { harmonization efficiency }\end{array}$ & $\begin{array}{l}\text { Total resource } \\
\text { potential }\end{array}$ & $\begin{array}{l}\text { Level of resource and } \\
\text { equipment provision of } \\
\text { company activities }\end{array}$ \\
\hline
\end{tabular}

Source: developed by the author on the basis of the systematized works ((Neely, Adams, Kennerley, 2003; Oleksyuk, 2009; Oleksyuk, 2008; Liashenko, 2008; Ishchenko, 2013; Sahaidak, 2015)

As for possibilities, there is certain inconsistency in the performance prism: their authors state that the processes will be effectively implemented if a company possesses corresponding possibilities - resources, skilled personnel, modern technologies, necessary infrastructure (Neely, Adams, Kennerley, 2003). This statement implies the identity of resources and possibilities.

Unlike in the performance prism with business processes presented by the lateral sides, in M. P. Sahaidak's prism, they are presented by internal diagonal planes. The difference between the processes in both prisms is conditioned by different purposes of the models.

\section{Key areas of stereometric method improvement exemplified by economic security}

So, the studied models on the basis of geometric figures do not completely consider the figures' properties. In particular, from stereometry we know about the following properties of the right prism: its lateral sides are rectangular, the lateral edges are equal to each other, the right prism is a rectangular one if its lateral edges form right angles with its base.

So, every prism studied is a polyhedron, two faces of which are congruent polygons lying in parallel planes, the other two faces are parallelograms having common edges with the polygons. Thus, every prism under study means parity of strategies, possibilities and business processes, which is not always so and requires additional explanation. This regards not only units of measurement which can be brought into accordance (e.g. (Neely et al., 2003) states that the process results can be measured in units of quality, quantity, time, handiness, money (price)) but also the very nature of the notions (there may be fewer strategies than business processes, fewer possibilities than business processes and strategies altogether).

Operationalization of properties of solids, on the basis of which an economic category is defined, is an important feature as without it the research cannot use such procedures as observation, measurement and loses the empirical essence (Hempel, 2000).

It should be noted that the models under study do not consider the fact that processes can be enhanced even if resources do not change (e.g. "learning-by-exporting" studied by D. Atkin, A. Khandelwal and A. Osman (Atkin, Khandelwal, Osman, 2017).

So, we think it is insufficient to have knowledge of solid shapes, faces, edges, vertexes, altitudes, volumes, etc. Measures of angles are of importance as well, but this fact is not considered in any of the models under study. Consider this further on the example of the model of economic security of the enterprise.

Considering the previous investigations, when determining a company's economic security, at first glance the pyramid similar to that of M. I. Ishchenko can be used and its elements can be interpreted correspondingly: the base area is the level of resource provision of economic security (the diagonals of a quadrilateral are traditional and non-traditional resources values), the altitude is the state of economic security, the angles are business processes of reaching and maintaining its level, the pyramid volume is the economic security level of a company. At that, resources and processes together can guarantee economic security to a certain degree. Let us consider the dynamics of the pyramid altitude and volume depending on measures of its angles. The elements were determined on the basis of a pyramid (the regular quadrilateral base with a segment length of 12.69 standard units and the same length of edges, the angles of 60 degrees each) applying "GeoGebra" (Table 6). 
Table 6

Dynamics of pyramid altitude and volume depending on measures of its angles

\begin{tabular}{|c|c|c|c|c|c|c|}
\hline \multirow[b]{2}{*}{$\begin{array}{l}\text { Lateral edge } \\
\text { length }\end{array}$} & \multicolumn{4}{|c|}{ Angles, degrees } & \multirow[b]{2}{*}{ Pyramid altitude } & \multirow[b]{2}{*}{ Pyramid volume } \\
\hline & $\begin{array}{c}\text { Angle at pyramid } \\
\text { vertex }\end{array}$ & $\begin{array}{l}\text { Linear angles } \\
\text { between lateral } \\
\text { and base edges }\end{array}$ & $\begin{array}{l}\text { Angles between } \\
\text { lateral faces }\end{array}$ & $\begin{array}{l}\text { Dihedral angles } \\
\text { between lateral } \\
\text { faces and base }\end{array}$ & & \\
\hline 24.48 & 30.0 & 75.0 & 93.6 & 74.4 & 22.78 & 1223.61 \\
\hline 12.69 & 60.0 & 60.0 & 99.6 & 54.7 & 8.98 & 482.19 \\
\hline 9.87 & 80.0 & 50.0 & 97.0 & 32.9 & 4.10 & 220.45 \\
\hline 8.98 & 90.0 & 45.0 & 90.0 & 0.0 & 0.0 & 0.0 \\
\hline
\end{tabular}

Source: developed by the author on the basis of "GeoGebra"

The following regularities should be mentioned, values of the pyramid base elements remaining unchanged: - the acuter the angle at the pyramid vertex (the angle between all lateral edges) is, the greater its altitude and volume values are and vice versa;

- decrease of the measure of the angle between lateral edges and the base of the pyramid results in a decrease of its altitude and volume and vice versa; the same dependency occurs when measures of dihedral angles between lateral faces and the base change.

Besides, angles at the base, between its faces, diagonals, between a diagonal and a face can be changed as well.

Thus, the obtained data confirms the fact that changes in quality, speed, and quantity of business processes expressed by changes in corresponding pyramid angles impact both the economic security state (the altitude value) and its general level (the pyramid volume). Changes of the angle at the vertex with the resource provision (the pyramid base) remaining unchanged results in changes of the edge length, the other angles measures, the altitude, and the volume.

The important omission of all the models based on the stereometric approach consists in the fact that none of them considers rules and principles of solid construction. It is known from school planimetrics that to construct an arbitrary quadrilateral it is not necessary to know lengths of its sides - it is quite sufficient to know the length of the diagonals and the angle between them. In terms of the present investigation, the interpretation of the latter can be as follows: to determine resource provision, data on the process and two kinds of resources should be available. In view of this, we think that to construct the economic security pyramid, all resources of a company should be divided into traditional and non-traditional that can graphically be presented as diagonals of the pyramid base - a quadrilateral, the angle between them represents the process of their formation (use). In this case, a simple question arises - if resource provision should be represented by a quadrilateral, or a triangle would be enough for this purpose. In accordance with planimetrics principles, to construct a triangle it is sufficient to know values of two sides and the angle between them, a side and two adjacent angles or three sides. In the first case, the third side and two other angles are constructed automatically; in the second case, two sides and the angle and, in the third case, all the angles are constructed automatically. Here, there are elements of the triangle conditioned by known elements and their values are insignificant, i.e. they are determined automatically.

So, if the base of the pyramid is a triangle with the established values of traditional and non-traditional resources and the process of their formation (use), the following problem requires further investigation - how to interpret the third side of the triangle as its value is determined automatically. Elements with insignificant values occur when constructing polygons with vertexes in different planes.

It should be noted that when considering such economic categories as competitiveness and development of a company, they can be graphically presented as a pyramid as they are based on ternary logic that focuses on their perception through resources, processes, and a state. On the one hand, economics already possesses tools of statistical inference for parametric estimation of the similitude function for both continuous and discrete variables. On the other hand, the stereometric approach suggests greater clearness. So, if to achieve a company's competitiveness and/or development, the resources similar to those required for providing its economic security, at least bases of the competitiveness pyramid, development pyramid and economic security pyramid will coincide. Besides, not only bases but also processes (measures of the angles) may coincide. In this case, the provision of competitiveness and/or development of the company mean reaching the state of economic security.

Thus, to enhance the state of economic security and increase its level, which are interpreted by us as the pyramid altitude and volume respectively, it is essential (without changing resource provision) to enhance corresponding business processes that is expressed by decreasing the angle at the pyramid vertex, increasing the angles between the lateral edges and the base edges and increasing the angles between the lateral faces and the base. When substantiating explanations of business processes, it should be taken into account that measures of the mentioned angles change simultaneously. 


\section{Conclusions}

Stereometric semantics used in models of determining particular economic categories does not always testify to implementation of the idea of applying geometric figures with vertexes in different planes. The stereometric approach is suggested to be meant as one of the economic analysis approaches based on visualization of economic categories and processes on the basis of geometric figures allowing qualitative and quantitative assessment of the level and dynamics of the selected array of indicators put into a single graphical model. This approach has not been formed as an individual research direction so far. The analysed models based on the stereometric approach neglect insignificant elements when using geometric solids in economics. This can be explained by the fact that all the selected parameters (faces, edges, planes, etc.) are treated as equivalent for assessment. Due to this, neglecting geometric figure construction rules, those of solids, in particular, may result in consideration of insignificant, irrelevant and unreal in the current conditions information. So, the application of the stereometric approach in the models with the mentioned omission does not produce a comprehensive idea and essence of economic categories (or an economic category) described by it. That is why such models are difficult to be implemented in practice. To enhance the stereometric approach, it is suggested to consider properties of geometric figures, rules of their construction, as well as focusing on angles that are proposed in economic interpretation to characterize corresponding business processes.

Thus, the stereometric approach to analysing economic categories and processes and its application in the science of security is a progressive, comprehensive and complex direction in economics requiring further research and substantiation of the array of its principles and methods and specification in every particular direction including the science of security and taxation.

\section{References:}

Atkin, D., Khandelwal, A. K., \& Osman, A. (2017). Exporting and Firm Performance: Evidence from a Randomized Experiment. The Quarterly Journal of Economics, 132(2), 551-615.

Beley, O.I. (2012). Pobudova modeli pryzmy efektyvnosti torhovelnoho pidpryiemstva [Building a trade enterprise performance prism]. Torhivlia, komertsiia, pidpryiemnytstvo, 14, 16-20. (in Ukrainian)

Biloshkurska, N. V. (2012). Vdoskonalennia ekonomiko-orhanizatsiinoho mekhanizmu ekonomichnoi bezpeky pidpryiemstv APK [Enhancement of the economic and organizational mechanism of economic security of agroindustrial complex enterprises]. Efektyvna ekonomika, 11. Retrieved from: http://www.economy.nayka.com.ua/ ?op $=1 \& \mathrm{z}=1081$ (in Ukrainian)

Chebanova, T. Ye., \& Koretska, O. V. (2015). Otsinka stiikosti ekonomichnoi bezpeky pidpryiemstv portovoi diialnosti [Assessment of economic security stability of port companies]. Rozvytok metodiv upravlinnia ta hospodariuvannia na transporti, 2(51), 55-71. (in Ukrainian)

Dotson, J. P. (2018). A Probit Model with Structured Covariance for Similarity Effects and Source of Volume Calculations. Journal of Marketing Research, 55(1), 35-47.

Drucker, P. (1994). Upravleniye dlya rezultatov [Managing for results]. Moscow: Texnichna shkola biznesu. (in Russian)

Ishchenko, M. I. (2013). Model otsinky resursnoho zabezpechennia finansovo-ekonomichnykh rezultativ diialnosti pidpryiemstva [The model of assessing resource provision of financial and economic results of an enterprise's activity]. Stratehiia ekonomichnoho rozvytku Ukrainy, 33, 220-228. (in Ukrainian)

Ishchenko, M. I. (2014). Metodolohichni osnovy otsinky finansovo-ekonomichnykh rezultativ diialnosti pidpryiemstv (na prykladi hirnycho zbahachuvalnykh kombinativ) [Methodological foundations of assessment of financial and economic results of enterprise performance (as exemplified by mining and concentrating enterprises)] (Doctoral dissertation). Kryvyi Rih: Kryvyi Rih National University. (in Ukrainian)

Gerasymenko, A., Borovyk, Iu., \& Afendikova, S. (2017). The methodology of competition assessment. Economic Annals - XXI, 165(5-6), 52-55.

Hempel, C. (2000). Science, Explanation, and Rationality: Aspects of the Philosophy of Carl G. Hempel. NY: Oxford University Press.

Holden, C. W., Jacobsen, S., \& Subrahmanyam, A. (2014). The Empirical Analysis of Liquidity. Foundations and Trends in Finance, 8(4), 263-365.

Juhn, C., McCue, K., Monti, H., \& Pierce, B. (2018). Firm Performance and the Volatility of Worker Earnings. Journal of Labor Economics, 36(1), 99-131.

Kirichenko, O. A., \& Shykova, O. M. (2011). Suchasne modeliuvannia system ekonomichnoi bezpeky [Modern Modeling of economic security systems]. Investytsii: praktyka ta dosvid, 3, 35-38. (in Ukrainian)

Korchevska, L. O. (2016). Metodolohiia synerhetychnoho upravlinnia ekonomichnoiu bezpekoiu pidpryiemstva [Methods of synergetic management of economic security of an enterprise: monograph]. Kherson: Private entrepreneur Vishimirsky V. S. (in Ukrainian)

Kretova, A. Yu. (2011). Tryvymirna model otsiniuvannia efektyvnosti diialnosti promyslovoho pidpryiemstva [A 3-D model of industrial enterprise performance assessment]. Ekonomika, Menedzhment, Pidpryiemnytstvo, 23 (II), 111-120. (in Ukrainian) 
Liashenko, O. M. (2008). Piramida efektyvnosti vzaiemouzghodzhennia interesiv yak instrument vymiriuvannia ekonomichnoi bezpeky pidpryiemstva [The pyramid of performance and mutual agreement of interests as a tool of measuring economic security of an enterprise]. Formuvannia rynkovoi ekonomiky, II, 396-401. (in Ukrainian)

Maslow, A. H. (1943). A Theory of Human Motivation. Originally Published in Psychological Review, 370-396.

McNair, C. J., Lunch, R. L., \& Cross, K. F. (1990). Do financial and nonfinancial performance measures have to agree? Management Accounting, 28-36.

Neely, A., Adams, C., \& Kennerley, M. (2003). Prizma proizvoditelnosti: sistema pokazateley dlya izmereniya $i$ upravleniya uspekhom $v$ biznese [The performance prism: The scorecard for measuring and managing business success]. Dnipropetrovsk: Balance-club. (in Ukrainian)

Oleksyuk, O. I. (2009). Tekhnolohiia otsinky rezultatyvnosti diialnosti pidpryiemstva [Technology of enterprise performance assessment]. Zbirnyk naukovykh prats CDTU, 22, 169-173. (in Ukrainian)

Oleksyuk, O. I. (2008). Teoretychni osnovy otsinky rezultatyvnosti diialnosti pidpryiemstv [Theoretical foundations of enterprise performance assessment]. Ekonomika ta pidpryiemnytstvo, 20, 192-202. (in Ukrainian)

Sahaidak, M. P. (2015). Metodychni pidkhody do modeliuvannia potentsialu vnutrishnoho marketynhu pidpryiemstv sfery posluh [Methodological approaches to modeling internal marketing potential of service enterprises]. Visnyk Skhidnoukrainskoho natsionalnoho universytetu im. V. Dalia, 4(221), 226-231. (in Ukrainian)

Sink, D. S. (1985). Productivity management: planning, measurement and evaluation, control, and improvement. New York: Wiley.

Tulchinskiy, G. K. (2017). Konstruktivizm i stereometricheskaya semantika: osnovaniya normativno-tsennostnogo sinteza v sotsialnykh naukakh [Constructivism and stereometric semantics: the foundations of normative-value synthesis in social sciences]. Chelovek. Kultura. Obrazovanye, 1(23), 32-42. (in Russian)

Zavorotnii, R. I. (2015). Stereometrychnyi pidkhid u otsintsi dynamiky hospodarskoho rozvytku pidpryiemstva [The stereometric approach to assessing dynamics of economic development of an enterprise]. Finansy Ukrainy, $8,101-113$. (in Ukrainian)

Zhuchkova, H. A. (2013). Rezultatyvnist diialnosti pidpryiemstva: naukovo-metodychni aspekty yii vyznachennia [Enterprise performance: research and methodological aspects of determination]. Efektyvna ekonomika, 11. Retrieved from: http://www.economy.nayka.com.ua/?op=1\&z=2517 (in Ukrainian) 